153,390. In 1962-63, 30.4 per cent of students were in science, 2.0 per cent in education, 5.4 per cent in engineering and technology, 3.9 per cent in medicine, and 2.5 per cent in agriculture. Postgraduate and research students totalled 76,594 in $1962-63$, of whom 17,317 were in science, 1,618 in engineering and technology, 2,498 in medicine, 1,757 in agriculture and 1,035 in education.

\section{Labour Market Policy in Sweden}

A Brochure, Labour Market Policy in Sweden, which has recently been issued by the Organization for Economic Co-operation and Development, initiates a series of reviews, country by country, of man-power policy and the social measures connected with it (OECD Reviews of Manpower and Social Policies. Pp. 72. Paris: Organization for Economic Co-operation and Development; London: H.M.S.O., 1963. 4 franes; $6 s . ; 1$ dollar). The review is in two parts. The first is a report by the Swedish authorities, which gives some basic data about Sweden and outlines the aims and philosophy which guide Sweden's man-power policy. The measures and means by which that policy is implemented are next described, including measures for stimulating mobility and creating employment. The second and shorter part of the review consists of the report of the examiners, Mr. Mansholt and Mr. Kirstein. This emphasizes two keynotes of Swedish policy: the conviction that it is necessary to intervene quickly when employment development calls for changes and adaptation of poliey; and the belief that full employment can only be achieved and maintained if the com. munity is prepared to invest the necessary public finance in current measures to adapt labour to current changes in conditions or production. Finally, there is a section by the Manpower and Social Affairs Committee summarizing the conclusions drawn from the review and a short bibliography.

\section{Productivity in British Industry}

THE Library Association has issued as Special Subject List No. 41 a bibliography on Productivity in British Industry, compiled by K. G. B. Bakewell, to which Graham Hutton contributes a foreword (Pp. 30. London: The Library Association, 1963. 6s.; L.A. members, 4s.). The 109 references are arranged under sub-headings dealing with such aspects as: defining and measuring productivity; factors affecting productivity; industrial relations and productivity; productivity in particular fields. Some reference material, bibliographies and periodicals are included, and there are subject, author and title indexes.

\section{Low-cost Automation}

Is its series under the general title Automation at Low Cost, the Department of Scientific and Industrial Research has produced a booklet by I. D. L. Ball, G. M. Lambert and T. L. Squires entitled Simple Automation of Machine Tools (Pp. 12. London: Information Division, Department of Seientific and Industrial Research, 1963). It is concerned with the application of conventional workshop machines of such devices as electrical, hydraulic and pneumatic control gear to give increased productivity at relatively low cost. So far as possible, particularly in the production of batch quantities, the equipment should be flexible in its application. That is, it should be transferable from, say, a large lathe to a smaller lathe, or from a lathe to a drilling machine, when it is desired to tool up for another job. The types of equipment described exemplify the various degrees of automation that might be attempted. First, there is an example of semi-automatic operation, together with a description of the devices, mostly inexpensive, that can be used. Then there is an instance of fully automatic operation, followed by an account of the additional flexibility achieved by programming the sequences of a production process or by using tracers. Some degree of automatic loading or assembly may be appropriate where production has been speeded up by the installation of new equipment.

\section{Training of Apprentices}

WiтH the Industrial Training Bill now on the Statute Book, interest in all forms of industrial training is rapidly growing. The Institute of Personnel Management has published a number of valuable Broadsheets, and the latest, Apprentice Training, could be of considerable assistance to those charged with developing training arrangements for future eraftsmen (Pp. 60. London: Institute of Personnel Management, 1963. 12s. 6d.). The authors, S. Crawford and E. G. Sterling, are in charge of the Technical College run by tho British Aeroplane Co., and use their considerable experience to provide practical details of a modern apprenticeship scheme and training at different levels: craft apprentices, technicians and technologists. The authors are critical of many aspects of the British system of apprenticeship, and hope that developments projected through the Industrial Training Bill will lead to the removal of practices which are at least one century out of date.

\section{Careers as Science Laboratory Technicians}

AN illustrated brochure, entitled Careers as Science Laboratory Technicians, has been issued by the Institute of Science Technology (Pp. 6. London: Institute of Seience Technology. Obtainable from F. W. L. Croker, Department of Chemistry, Imperial College of Science and Technology, 1964). The brochure outlines the aims and services of the Institute, which is a registering body of science laboratory technicians. Besides describing the work of laboratory technicians and the prospects offered by such a career, it gives details of the Institute's publications and membership.

\section{Soil Research in Australia}

THE report for $1962-63$ of the C.S.I.R.O. Division of Soils (Pp. 112. C.S.I.R.O. Division of Soils, Adelaide, 1963) covers a wide field of activities in soil investigation, including pedology, chemistry, physies, microbiology, mineralogy, micropedology and fertility. The practical aspects of land-use, based on fundamental studies, are tending to replace the former survey and mapping techniques, but a soil map of Central Australia has been added to the Atlas of Australian Soils and an examination has been made of the seventh approximation in relation to Australian soils. A good deal of attention is being directed to water balance of pasture land. ground water régime and the influence of permeability of porous materials and evaporation on water movement. There have been investigations on the acid groups of soil elays, of the release of potassium from micas, of the effects of phosphorus on yield and quality of wheat, and of gypsum on emergence response in different soils. Foliar analysis is being used to supplement the investigations on fertilizers for forest trees and labelled nitrogen in field studies of pastures. With respect to trace elements, work is in progress on their frequency of distribution, their sorption by clay minerals, their availability and deficiencies in the field with special regard to copper, zinc, cobalt and molybdenum. The bioassay of soil toxicity, which seems to be greatest in soils recently cleared of native vegetation, and the identification of the toxins, are being studied, as are tho stimulation of plants by bacterial inoculation and the degradation of synthetic phenol-amino-acid polymers. There is also information on developments in microanalysis.

\section{Dating of Ore Deposits by Palæomagnetism}

THE first extensive application of the study of palæomagnetism to the dating of ore deposits has lately been undertaken by the Geological Survey of Czechoslovakia in co-operation with the Czechoslovak Institute of Applied 